\title{
Dentists' attitude towards their role in children and adolescent obesity control in the dental office
}

\author{
Ana-Maria Jurca Bud ${ }^{1}$, Aurel-Claudiu Vartolomei², Eugen Bud², Alexandru Zalana², \\ Mariana Pacurar ${ }^{2}$ \\ ${ }^{1}$ Pedodontics Department, Faculty of Dental Medicine, University of Medicine and Pharmacy, \\ Tg. Mures, România \\ 2Orthodontics Department, Faculty of Dental Medicine, University of Medicine and Pharmacy, \\ Tg. Mures, România
}

\begin{abstract}
Although the correlation between the nutritional status and tooth decay is an actual subject in literature, the role of the dentist, particularly the pediatric dentist, in the prevention of obesity in children and adolescents is least studied. (1) While in the past the evaluation of the nutritional status of the child was the responsability of the pediatrician or the general practitioner, nowadays, the high rates of obesity require the modification of this protocol which has become unsatisfactory. The dentist has high potential to perform obesity screening, taking into consideration the regular, generally bianual, doctor visits compared to the sole pediatrician visit, especially when there is no vaccination time.

We have performed a clinico-statistical study among different specialty dentists by means of a questionary comprising 13 questions, virtually delivered, with the purpose of obtaining data concerning the involvement of the dentist in the complex issue of nutrition as one of the etiological factors of tooth decay. The results indicate a high interest of the respondents in this matter but with relatively low implication due to lack of time and indistinctive examination protocols.

This study offers a picture of the opinions different specialty dentists in Romania have about the role of the dentist in the screening of infantile obesity and about the present but also future attitudes concerning this major health problem. The dentist, especially the pedodontist, is in an unique position of being able to influence the nutrition habbits of children. Due to periodic doctor visits, they are able to monitorize not only oral health but also the nutritional status.
\end{abstract}

Keywords: overweight, attitude, prevention, nutrition, children

\section{INTRODUCTION}

The obesity rate in children and adolescents is continuously growing worldwide, hitting alarming peaks, including in Romania. Besides the medical complications, such as high risk of type 2 diabetes, heart disease, some forms of cancer, variable respiratory disorders and oral impairments, such as tooth decay, xorostomy, periodontal disease, it also has psychological implications as the patients are prone to depression and low quality life $(4,5)$. Obesity is a health system and economy issue not only in developed countries but also in low income countries. Despite all this, the problem of children obesity is frequently neglected and real involvment of pedia- tricians and pedodontists is necessary in the elaboration of clinical protocols that are meant to help diagnosis and treatment of overweight and of obesity (2).

Several studies indicate that a frequent intake of refined carbohydrates and sweetend beverages is one of the major factors in the epidemiology of obesity and tooth decay. Therefore, the attention must be focused on children because during childhood certain behaviours, preferences and nutrition habbits are formed; these will affect the later adult evolution.

The dentists has the opportunity to be involved in the prevention of obesity in children and adolescents, taking into consideration that they keep 
young children under observation. These interventions must be done as soon as possible because many of the obese children become obese adults with associated risks and complications. Given that dentists currently provide nutrition advice in the sense of reducing cariogenic food and habbits, the introduction of minor measures in the examination routine would be extremely useful, with emphasis on obesity and its severe consequences (3). The advertising of healthy nutrition, reduced sugar intake, regular meal schedule with unhealthy snaks exclusion and replacement with fresh fruit and vegetables are commom methods of reducing obesity and decay, especially early decay.

\section{AIM OF STUDY}

The aim of this study was to determine the role of the Romanian dentist in the prevention and control of overweight and obesity in children and adolescents. We reviewed the current attitude of dentists in this matter and the chances that in the future an extra step for nutrition counseling be included in the working protocol.

\section{MATERIAL AND METHDS}

We conceived an original questionnaire with 13 items which was delivered by e-mail and social networks to the dentists of different specialties from various university centers. The questionary addressed to the dentists was conceived so that it supplied information about their opinions and about their actual actions they perform in the proposed matter. Before filling in the questionary, the doctors were informed about the purpose of the study and that their answers were anonymous and did not imply any responsability. The first five questions contain data about the dentist, as it can be observed in Fig. 1.

The questionnaire was delivered to 400 doctors, out of which 186 responded. The next seven questions were based on the role of the dentist in obesity control and the possible solutions in the dentists' attitude, as well as in the way of interaction with other specialty colleagues. They aim present attitudes but also intentions of the doctor concerning these aspects. From the last multiple choice question we tried to identify the main obstacles in the approach of this subject (Fig. 2).

\section{ROLUL MEDICULUI STOMATOLOG ÎN COMBATEREA OBEZITĂTIII LA COPII \\ "Obligatoriu \\ 1. Sex* \\ Marcati un singur oval. \\ Feminin \\ Masculin \\ 2. În ce mediul lucraţi?* \\ Marcati un singur oval. \\ Rural \\ Urban \\ 3. Tipul cabinetului" \\ Marcati un singur oval. \\ Clinică privată \\ Clinică stat}

4. Numărul de ani de practicā*

Marcati un singur oval.

Sub 5 ani

5-10 ani

11-15 ani

$16-20$ ani

$21-30$ ani

Peste 30 ani

5. Gradul și specialitatea profesională*

Marcati un singur oval.

Medic retident

Medic specialistprimar Ortodonție/Pedodonție

Alte specialitätri

FIGURE 1. First section of the questionary, demographic characteristics

\section{RESULTS}

Out of the 186 respondents, 179 answered all the questions. 7 dentists filled in only the first 5 qustions and were excluded from the study. Concerning the sex of the respondents, females prevailed $(77.09 \%)$. Sex distribution is represented in Fig. 3.

The majority of respondents $(90.50 \%)$ come from urban environemnt and practice in private offices (Fig. 5). From the total respondents, 38\% were young doctors with less than 5 years of clinical experience followed by the ones with 5 to 10 years of experience, meaning $30.2 \%$. A percentage of 11.7 have 11 to 15 years of experience and $9.5 \%$ have been practicing dentistry for 16 to 20 years. A low number of respondents belonged to 21 to 30 and over 30 years of clinical activity groups (Fig. 6). 


\section{ROLUL MEDICULUI STOMATOLOG \\ ÎN COMBATEREA OBEZITĂTYII LA COPII}

intrebãrile urmátoare se referà la pacienții copii și adolescenți

6. Considerați că medicul dentist are un rol in identificarea și combaterea tulburảrilor nutriționale? Marcați un singur oval.

$\mathrm{Da}$

$\mathrm{Nu}$

Nu știu

7. Consideraţi importantă evaluarea obiceiurilor alimentare?*

Marcati un singur oval.

$\mathrm{Da}$

$\mathrm{Nu}$

Nuștiu

8. Notați in mod curent in fişa pacienților dacă sunt supraponderali sau obezi?* Marcati un singur oval.

Intotdeauna

Uneori

Niciodată

Nu, dar aș fi dispus să o fac in vitor

9. Discutaţi cu părinţii despre existenţa semnelor de supraponderalitate/obezitate?*

Marcati un singur oval.

Intotdeauna

Uneori

Niciodatá

Nu, dar aș fi dispus să o fac in vitor

10. Oferiți consiliere sau materiale educaţionale pe această temă a nutriției?*

Marcati un singur oval.

Intotdeauna

Uneori

Niciodatá

Nu, dar aș fi dispus să o fac în viitor

11. İndrumați pacienții identificați ca supraponderali/obezi către medicul specialist, nutriționist sau diabetician?*

Marcafi un singur oval.

Intotdeauna

Uneori

Niciodată

Nu, dar aș fî dispus sā o fac in vittor

12. Informați părinţii că există risc crescut de carie?*

Marcați un singur oval.

Intotdeauna

Uneori

Niciodată

Nu, dar aș fi dispus sā o fac in viitor

13. Oferiți informații sau materiale legate de consumul crescut de zahăr și băuturi indulcite?* Marcati un singur oval.

Intotdeauna

Uneori

Niciodată

Nu, dar aș fi dispus să o fac in viitor

14. Care considerați că ar fi dificultățile in misiunea medicului dentist privind consilierea nutrițională?" Bifati toate variantele aplicabile.

Lipsa unui protocol clar

Lipsa cunoştințelor suficiente a medicului dentist in acest domeniu

Lipsa acordului părintelui de a primi recomandāri nutriţonale de la medicul dentist

Teama de a nu jigni pãrintiilicopilul

FIGURE 2. Second section of the questionnary 


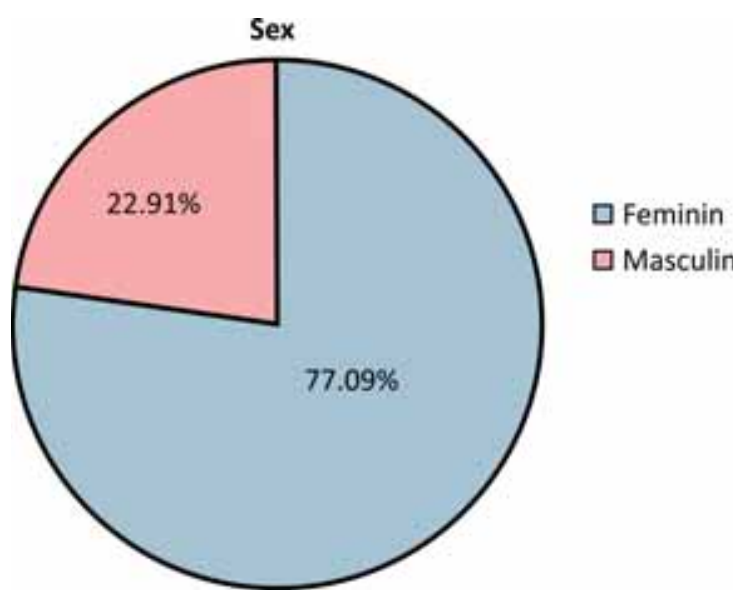

FIGURE 3. Lot sex distribution

This demonstrates higher receptivity in young doctors. One explanation could be the fact that the survey was performed online and by social media networks which are more frequently accessed by young doctors. The vast majority of the questioned doctors were general dentists (53.63\%) followed by a rate of 26.26 of orthodontics and pedodontics doctors, $11.73 \%$ of other specialties and in addition $8.28 \%$ of resident doctors.

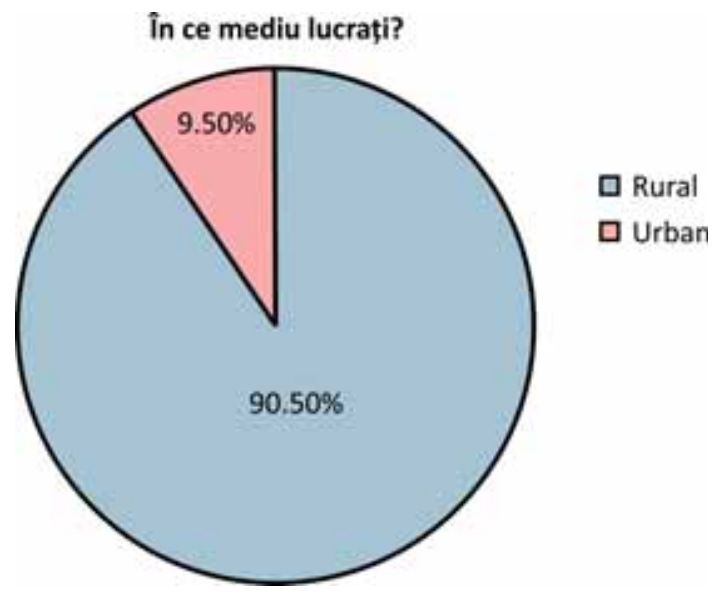

FIGURE 4. Environment activity lot distribution

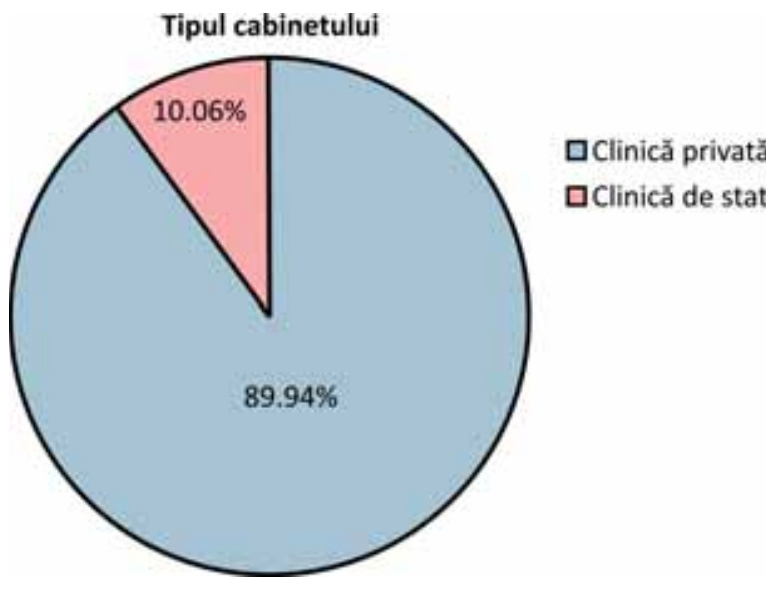

FIGURE 5. Type of office lot distribution

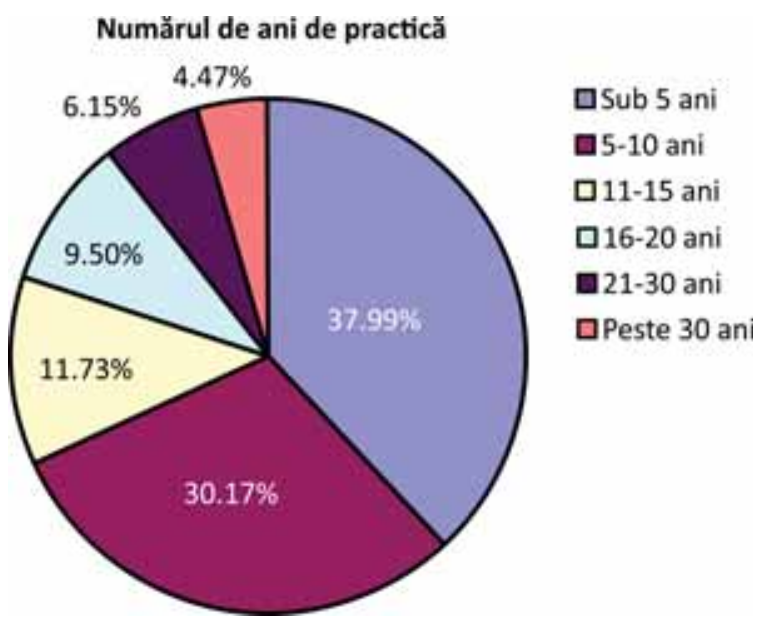

FIGURE 6. Years of clinical experience lot distribution

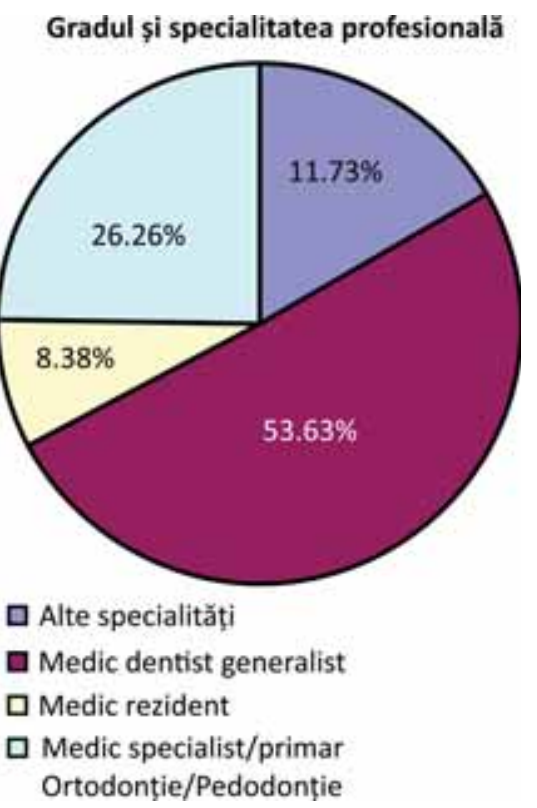

FIGURE 7. Professional specialty lot distribution

The second section of the questionary started with an inquiry concerning the role of the dentist in identifying and controlling nutrition disorders in children and adolescents. We noticed that a high percentage $(75.98 \%)$ of the questioned doctors responded affirmatively to this question, which indicates willingness to get involved in tracing and analysing several etiological factors mutual to both tooth decay and nutrition disorders (Fig. 8). We found no significant differences between doctor specialties in this question (p-0.11). Still, a slightly higher percentage of the pedodontists responded positively to this question: $89.4 \%$ compared to $68.8 \%$ general dentists and $76.2 \%$ other specialties.

Concerning the importance of the doctor's evaluation of the nutrition habbits, there is a relative unanimity in answers as most respondents (93.85\%) 


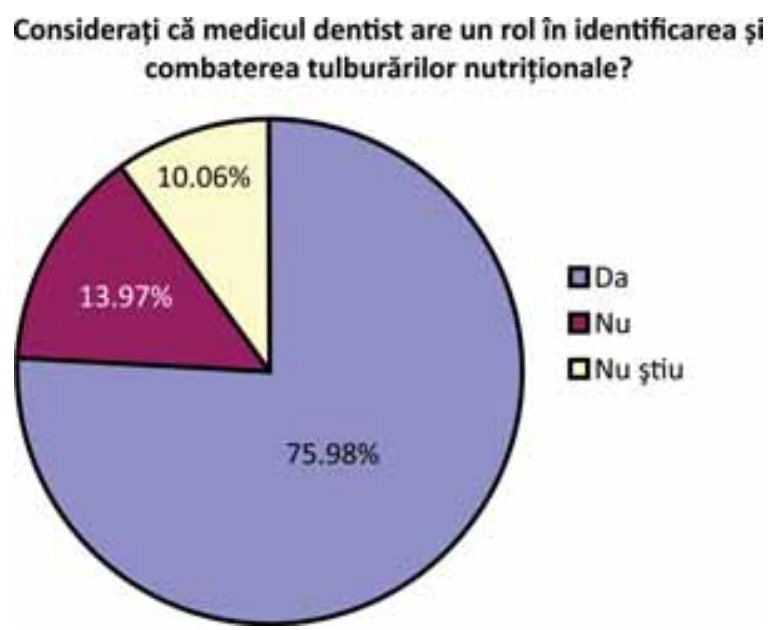

FIGURE 8. The role of the dentist in nutrition

Consideraţi importantă evaluarea obiceiurilor alimentare?

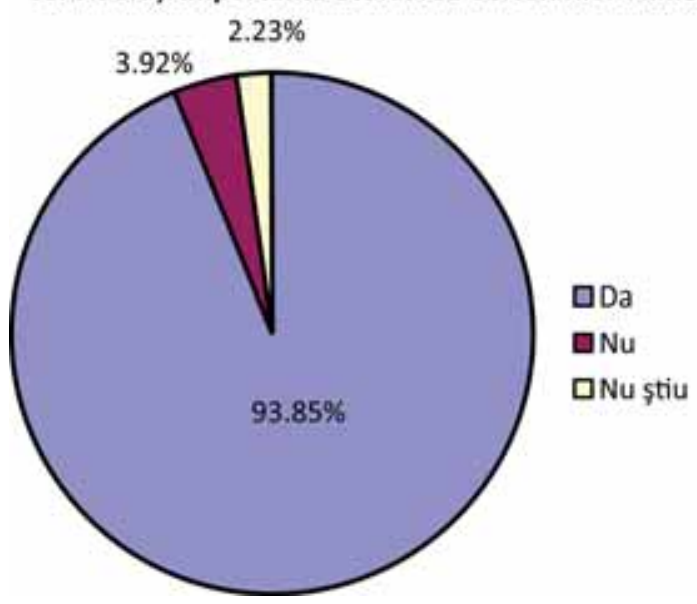

FIGURE 9. Nutrition disorders control lot distribution habbits evaluation

agree in a $90 \%$ rate with the importance of the approach to this aspect in the patient's medical history, regardless of the specialty (p-0.58). Only 7 respondents $(3.9 \%)$ do not consider that the evaluation of nutrition habbits comes to the dentist's duty while 2,2\% answered elusively, "I do not know".

The proportion of doctors who write down in the patient's file the presence of overweight and obesity signs is represented in figure 10 . A very low percentage of doctors $(7.82 \%)$ always register in the clinical file the existence of nutrition disorders; this suggests only isolated actions which do not make the object of constant concern. In similar percentages one can identify the doctors who occasionally take notes $(20.67 \%)$ and the ones who never take these aspects into consideration $(21.33 \%)$. Half of the questioned doctors are open to this issue and are willing to modify thier examination protocol in the future by registering patients at risk (Fig. 10). A considerable fraction of the respondents $(45.81 \%)$ discuss the overweight problem with the parents. Aproximately one third of the doctors $(30.17 \%)$ do not currently talk to the parents about these aspects but are willing to advise them in the future even it would increase the consultation time (Fig. 11).

\section{Notaţ̧i în mod curent în fișa pacienților dacă sunt supraponderali sau obezi?}

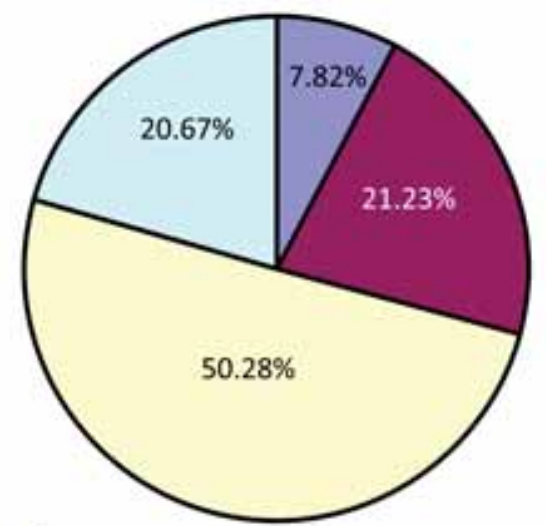

Î̀ntotdeauna

ㄱiciodată

Nu, dar aș fi dispus să o fac în viitor

ㅁ Uneori

FIGURE 10. Dentists' answers to question no 8

Discutați cu părinţii despre existența semnelor de supraponderalitate/obezitate?

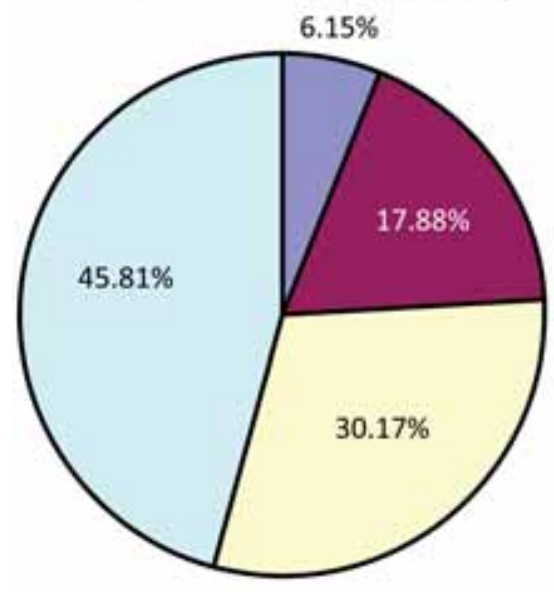

ㅁ Întotdeauna

- Niciodată

ㅁ Nu, dar aș fi dispus să o fac în viitor

$\square$ Uneori

FIGURE 11. Dentists' answers to question no 9

Regarding educational material distribution and nutrition counseling, $31.28 \%$ of the respondents confirmed they engage in these aspects but not always. A percentage of 25.14 did not manifest any interest in offering nutritional aspect information to 
patients and $41.34 \%$ consider it a useful practice for the future. The very low rate of doctors which are involved in the aspects concerning nutrition and diet issues is an alarm for the inclusion of this subject in subsequent information campaigns, in collaboration with diebetologists.

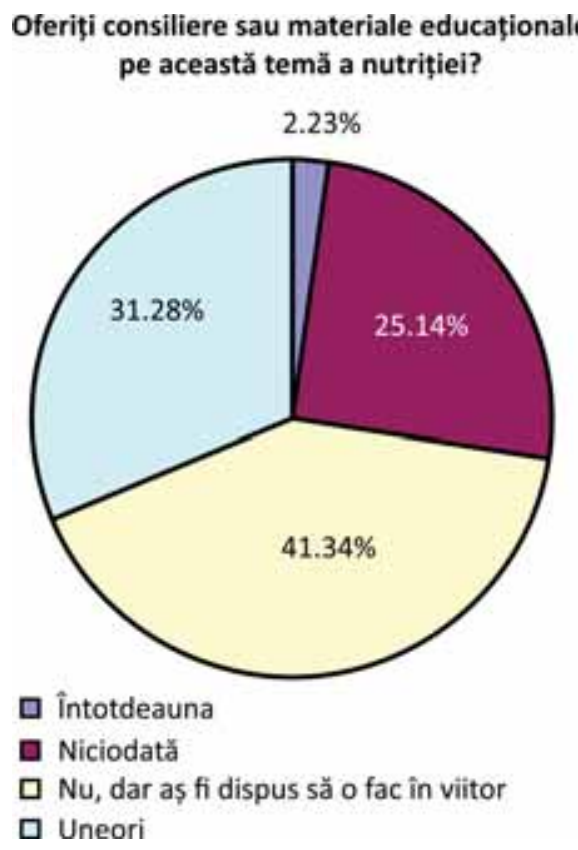

FIGURE 12. Nutrition counseling lot distribution

Îndrumaţi pacienţii idenfiticaţi ca supraponderali/obezi către medicul specialist, nutriţionist sau dietetician?

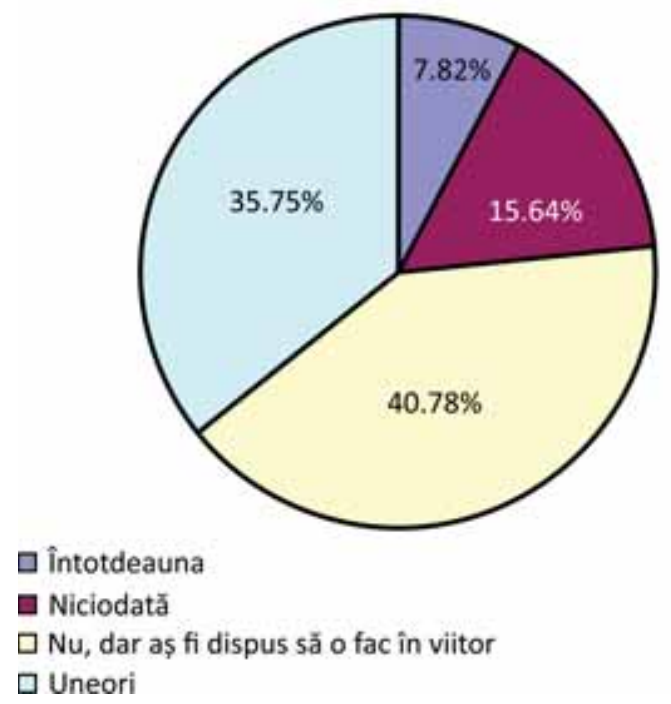

FIGURE 13. Interdisciplinary collaboration ratio

We have evaluated the existence of an interdisciplinary collaboration, a fundamental concept in modern medicine, between the dentist and the pediatrician with counseling from a dietitian in choosing caloric balanced but tastetful meals for children.
The results obtained point out the necessity of strategy elaboration for the improvement of interdisciplinary collaboration because only a low percentage of the questioned doctors $(7.82 \%)$ refer their patients to a specialist for nutrition counseling. However, almost half of the dentists are open to collaboration in the future. Their answers are presented in Fig. 13.

The approach on the subject concerning a high risk of decay is accepted by the majority of the dentists as almost all the respondents (83.8\%) inform their patients and their carers about decay increased risk (Fig. 14). A very low rate $(2.23 \%)$ do not consider the information regarding tooth decay risks necessary for the patients while $11.73 \%$ do it sporadically.

\section{Informaţi părinții că există un risc crescut de carie?}

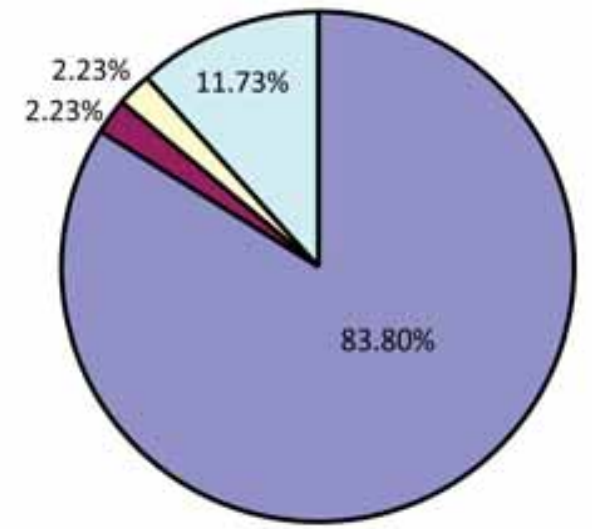
$\square$ Întotdeauna
Niciodată
$\square \mathrm{Nu}$, dar aş fi dispus să o fac în viitor
$\square$ Uneori

FIGURE 14. Doctors' answers to question no 12

\section{Oferiţi informații sau materiale legate de consumul crescut de zahăr și de băuturi îndulcite?}

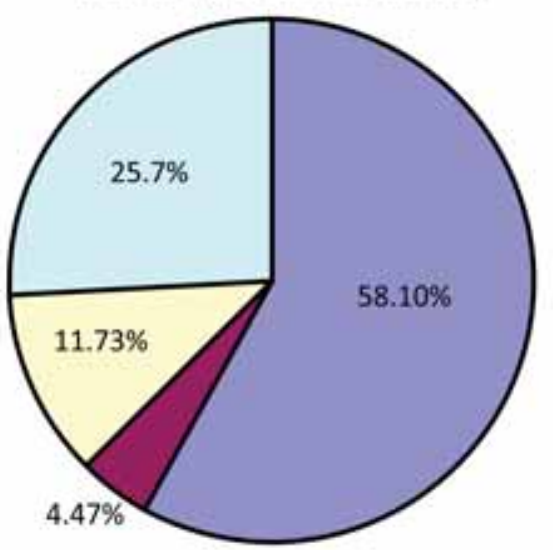

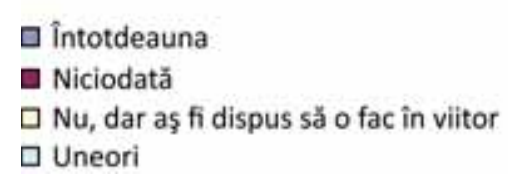

FIGURE 15. Doctors' answers to question no 13 
In order to have a more precise idea about one of the mutual risk factors of decay and overweight, refined sugar and sweetened beverages intake, we asked the dentists if they provide information or materials on this matter. The answers are different by means that more than half of the respondents always provide information or materials regarding increased intake of sugar and sweetened beverages (58.1\%) while a lower percentage of 11.73 do not currently do it but are willing to in the future.

When asked about the difficulties in the dentist's involvement in providing nutrition services, the lack of a precise protocol made it to the top of the list. Thus, the following are necessary: advertising mechanisms, elaboration of guidelines for patients with overweight risk and nutrition habits reorientation to a healthy diet. Fear of offending the child or the parent followed, then lack of sufficient knowledge in this domain as well as the difficulty of addressing the subject. Other impediments mentioned by the doctors are the lack of parents' agreement and lack of time during the daily schedule (Fig. 16). The matter of an optimal approach to this theme now arises as well as the method to include infant obesity screening in the dental examination.

\section{DISCUSSIONS}

From an epidemiological point of view, Romania meets the profile of developed countries, with a high incidence of obesity and infantile overweight and is among the leading spots of European countries. Less and less time is invested in cooking, con- venience, fast-food prevails, with refined sugar and diverse added additives which to make it hypercaloric and unhealthy. It is crucial that the parents observe the modifications of the child's body mass on time or that they be raised awarness by the doctor about the methods of obesity control and its risks. (2) The parents must be informed about the importance of avoiding hypercaloric nourishment (cakes, chocolate, sweetened beverages) and about the consequences of a growing rhythm that leads to obesity (1).

A national study on the role of the dentist in obesity approach across the US in the University of North Carolina in 2012 discovered that most of the dentists did not offer infantile obesity screening services. The study comprised almost 3,000 general dentists and pedodontists. (Currank) Similar to the results obtained in our study, young doctors, especially females, pedodontics specialists, with less than 10 years of clinical activity were more open to providing services regarding obesity in the dental office. (Tseng R) Regarding difficulties encountered in providing these services in the dental office, in their study, the fear of offending the patient or the parents came first while our results showed that the lack of a sheer protocol was the main reason. Other impediments encountered by the American doctors were: fear of not seeming critic, lack of specialized personal, patient's reluctance to the dentist's guidance, lack of time in the daily schedule, lack of knowledge.

These results emphasise the importance of including in dental and dental assistance study pro-

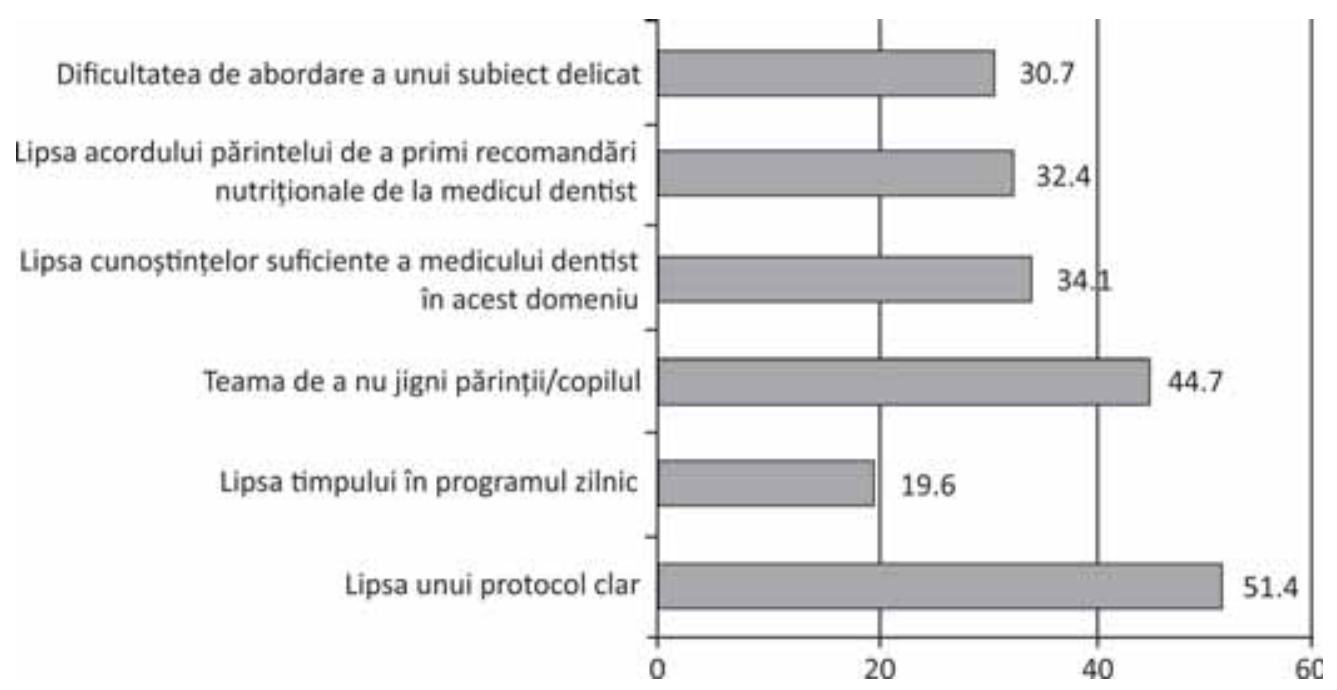

FIGURE 16. Difficulties encountered by dentists in nutrition counseling 
grams notions of nutrition, balanced diet and as well as the method of calculating and interpreting the BMI in children and adolescents. Also, it is important to assimilate notions of psychology with the purpose of tactical, respectful and sensible approach of the obese patient. The doctors attitude must not be critic but empathic, without any judgement towards the child and the parents, using a non-stigmatizing language. The phrases "body mass which is not optimal" or "an increased BMI" are prefered to the "obese" or "fat" expressions in the case delicate children and parents.

A recent study performed online by the American Academy of Pediatric Dentistry (AAPD) which comprised about 7450 pediatric dentists shows that $17 \%$ of them are interested in the obesity issue and from the ones that are not, $67 \%$ are be willing to get involved in this matter in the future. A percentage of 94 of the inquired American dentists provide to the patients information on the effects of sweetened beverages consumption on the dental and general health status. (Wright) An appreciable percentage of 73 of the doctors in the USA agreed with the role of the dentist in obtaining a weight suitable for the age. We have obtained similar results in the present study as $76 \%$ of the dentists agree with their role in obesity control, respective $89.4 \%$ of the pedodontics or orthodontics specialists. The most significant impediment in providing nutrition counseling was the lack of time in the daily schedule followed by lack of qualified personal and of sufficient knowledge on infantile obesity.

\section{REFERENCES}

1. Portuguese Dentists' Attitudes Towards Their Role in Addressing Obesity. Oral Health Prev Dent, 2016;14(1):1320.

2. Baker Suher, Yagiela J.A. Obesity: a complicating factor for sedation in children. Pediatr Dent 2006; 28:487-493

3. Guo S., Dipietro L.A. Factors affecting wound healing. J Dent Res 2010; 89:219-229

4. Tseng R., Vann W.F., Perrin E.M. Addressing Childhood Overweight and Obesity in the Dental Office: Rationale and Practical Guidelines. Pediatric Dentistry. 2010; 32(5):417

5. Wright R., Casamassimo P.S. Assessing attitudes and actions of pediatric dentists toward childhood obesity and sugar-sweetened beverages. J Public Health Dent. 2017 Jun; 77 Suppl 1:S79-S87).

6. Christoforou J., Huang B. Relationship between children's body mass index and saliva buffering capacity Australian

\section{CONCLUSIONS}

The alarming incidence increase in infantile obesity is one of the most important medico-social problems of this century, with repercussion on health status and life quality and for which's control a mutual effort from all the specialists is necessary.

Healthy nutrition choices, with sugar intake reduction, must be educated by the family, by society and by school, as soon as possible during childhood. These can reduce the risk of decay and have an important role in obesity prevention, being the premise of a future healthy generation.

The dentist is in ideal position to perform obesity and infant overweight screening and to provide advice regarding the diet on periodical dental appointments.

A relatively high rate of respondents admit the lack of satisfactory knowledge in this area, although there is high receptivity and willingness of the questioned doctors in the approach of obesity issues.

The development of communication strategies with the parents and the child, of medical education actions for tactical, respectful and sensible approach to this delicate subject concerning the child's weight is a useful method of decay prevention and quality life increase.

Conflict of interest: none declared Financial support: none declared

Dental Journal ADRF Special Research Supplement 2007; $52 ; 4)$

7. Pikramenou V., Dimitraki D., Zoumpoulakis M.,Verykouki E., Kotsanos N. Association between dental caries and body mass in preschool children. Eur Arch Paediatr Dent 2016; 17: 171-175.)

8. Chen D., Zhi Q., Zhou Y., Tao Y., Wu L., Lin H. Association between Dental Caries and BMI in Children: A Systematic Review and Meta-Analysis. Caries Res. 2018; 52(3):230-245.)

9. Frias-Bulhosa J., Barbosa P., Gomes E., Vieira M.R., Manso M.C. Association between body mass index and caries among 13-year-old population in Castelo de Paiva, Portugal. Rev Port Estomatol Med Dent Maxilofaciala 2015; 56: 